\section{Öğretmen Adaylarının Bir Matematik Öğretmeni Olarak Kendilerine ve Matematiği Öğrenen Öğrenciye Yönelik İmajları*}

Türk Eğitim Bilimleri Dergisi

Makale Türü: Araştırma

Makale Geliş Tarihi: 09.04.20

Makale Kabul Tarihi: 09.06.20

Makale Yayın Tarihi: 26.06.20

\author{
Funda Uysal ${ }^{1}$ Hünkâr Korkmaz ${ }^{2}$
}

\title{
Öz
}

Tarama deseniyle yürütülen bu araştırmanın amacı hizmet öncesi öğretmen adaylarının bir matematik öğretmeni olarak kendilerine ve matematiği öğrenen öğrenciye yönelik imajlarını incelemektedir. Araştırmaya 424 hizmet öncesi öğretmen adayı katılmıştır. Verileri toplamak için projektif bir test olan çizim testi kullanılmıştır. Verilerin analizinde temalar ve kodlar belirlenmiş, frekans ve yüzdelere yer verilmiştir. Öğretmen adayları; kendilerini matematik öğretmeni olarak hayal ettikleri çizimlerinde matematik öğretmeninin en çok ders anlattığını, öğrencilerin en çok ders dinlediğini ifade etmişlerdir. Diğer taraftan çizimlerinde matematik öğretmeninin en az olumsuz duyguya sahip olduğu ve sinav yaptı̆̆ını; matematiği öğrenen öğrencilerin en az derse ilgisiz ya da sınav olduğunu ifade etmişlerdir. Matematik öğretmeninin çoğunlukla güleryüzlü, ayakta olduğu ve yazı tahtalarına daha çok dört işlem ifadelerini yazdığını gösteren çizimler yapmışlardır. Matematiği öğrenen öğrencilerin çoğunlukla sıralarında olduğunu göstermişlerdir. Bu çalışmanın bulgularının matematik programları, matematik eğitimi, öğretmen eğitimi ve imajlar konularında çalışma yapacak olan araştırmacılara, eğitimcilere ve politika yapıcılara katkı sağlayacağı düşünülmektedir.

Anahtar Sözcükler: Hizmet öncesi öğretmen eğitimi, İmaj, Matematik öğretmenine yönelik imaj, Matematiği öğrenen öğrenciye yönelik imaj, Matematik eğitimi.

\begin{abstract}
This study aims to investigate the images of first- and fourth-year elementary mathematics, science and elementary education teacher candidates about mathematics teachers and students. In the survey research, it was tried to describe the perceptions of teacher candidates about mathematics teachers and students. 424 teacher candidates participated in the study. Data were collected by using, a projective test, a drawing form for teacher candidates. For the analyses of data, themes and codes were identified, and percentages were reported for the statements "often, rarely, never". In their drawings where the teacher candidates imagined themselves as mathematics teachers, they most commonly represented the mathematics teacher as lecturing and students as listening to the lecture. On the other hand in their drawings at least, they stated that the mathematics teacher has a negative feeling and makes the exam; students learning mathematics are indifferent to the lesson or have an exam. They made drawings that showed that the mathematics teacher was mostly smiling, standing and writing four operations on the whiteboards. They showed that students learning mathematics were mostly on their desks. It is supposed that the results of the study will be able to provide useful contribution for educators, policy makers, and researchers studied in math curriculum and instruction, teacher education, and images.
\end{abstract}

*Bu makale, "Öğretmen Adaylarının Matematiğe Yönelik İmajları, Tutumları ve Akademik Başarıları Arasındaki İlişkinin İncelenmesi" başlıklı doktora tezinin bir bölümünden üretilmiştir.

${ }^{1}$ Funda Uysal, Arş. Gör. Dr., Burdur Mehmet Akif Ersoy Üniversitesi, fuysal@mehmetakif.edu.tr

${ }^{2}$ Hünkar Korkmaz, Prof. Dr., Hacettepe Üniversitesi, hunkar@hacettepe.edu.tr 
Keywords: Pre-service teacher education, image, Image of mathematics teachers, image of mathematics students, mathematics education.

\section{Giriş}

Yaşam ve ekonominin küreselleşmesi, değişen değerler, bilgi ve iletişim teknolojilerinde oluşan yenilikler genel olarak eğitim ve öğretime, özelde ise öğretmen eğitimine etki etmektedir. Bu bağlamda açık ve dinamik bir sistem olması gereken öğretmen eğitiminde, Avrupa Birliği Öğretmen Yetiştirme Raporu'na göre, öğretmenler; bilimsel verilere dayalı bilgilerle donanmış, etkili öğretme-öğrenme sürecini gerçekleştirebilmek üzere zengin yaşantılara sahip, öğrencileriyle ilgilenen, entelektüel, eleştirel düşünebilen, meslek etiğini benimsemiş kişiler olmalıdır (YÖK, 2007). Öğretmenlerin belirtilen özelliklere sahip olması sadece dâhil olacakları öğretmen yetiştirme programlarından değil, programa başlamadan önceki yaşantılarından da kaynaklanabilir.

Öğretmenler, konu alanı ve uygulamaya yönelik mesleki bilgilerini sürekli güncelleyen ve kendilerini geliştirmek için farklı yöntemlere başvuran bireylerdir. Edge (1992) bu durumu şöyle ifade etmiştir;

Bir öğretmen olarak kendimi değerlendirmek istiyorum. Ama önce ne yaptığımı görmem ve anlamam gerekiyor, bunu da tek başıma yapamam. İşte paradoks burada. Gelişim derken ben bireysel gelişimi kastediyorum, ancak bu yalnız başına olacak bir şey değil. Bireysel gelişim için başka insanlara gereksinim var: öğrencilere, meslektaşlara (s. 4; akt. Yalaz Atay, 2003).

Çakmak (2001) etkili öğretmenlerin; konu alanı bilgisinin güçlü, öğretim tekniklerini, stratejilerini yenileyebilen ve uygulayabilen, kendilerini geliştirebilen, öğrencilerini güdüleyen, izleyebilen, değerlendirebilen, öğrencileriyle etkili iletişim kurabilen, güvenilir, açık ve tutarlı bir kişiliğe sahip, başarıyı sağlayabilen bireyler olduğunu ifade etmiştir (Akt. Bozdoğan, 2004). Etkili öğretimin gerçekleşebilmesi için öğretmenlik mesleği genel yeterlikleri ve öğretmen eğitimi standartları konularında yapılan çalışmalarda (MEB, 2017, OECD, 2013) öğretmenlerin, özel alan bilgisi bağlamında yetkin; öğretmenlik meslek bilgisi bağlamında hedeflere uygun öğretim yöntem ve tekniklerini uygulayarak, değerlendirme yapabilen, öğrencilerini motive eden; genel kültür bağlamında kendini geliştirebilen bireyler olması gerektiği vurgulanmaktadır. Evreni anlamlandırma ve gerçeği bulmada önemli olan ve günlük hayattaki problemlerin çözülmesini sağlayan matematiğin de etkili bir şekilde öğretilmesi için matematik öğretmenlerinin gelişimine önem verilmelidir.

Amerikan Ulusal Matematik Öğretmenleri Konseyi (National Council of Teachers of Mathematics [NCTM], 2000) etkili bir matematik eğitimi ve öğretmen nitelikleri için belirlenen ölçütleri özetle şu şekilde ifade etmektedir: (a) İyi bir matematik öğretimi etkinliklerden daha fazlası olup matematiğin önemine odaklanmalıdır. (b) Matematik dersinin içeriği, öğrencilere çoklu bakış açısı kazandırmalıdır. (c) Öğretmenlerin bilgi ve becerilerini, öğretim materyalleri, yöntemleri, stratejileri ve 
çıktıları kullanma ve değerlendirmeye yönelik kullanımlarını geliştirmelidir. (d) Öğretmenlerin mesleki gelişme ve yetişmelerine imkân vermelidir. (e) Öğretmenler mesleki gelişim süreçlerine ilişkin kararlarda etkin bir rol almalıdır.

Diğer taraftan matematiğin doğasına ve ders çalışmanın amacına ilişkin olarak iletişim halinde olan yüksek beceri ve motivasyona sahip öğretmenler, matematik programlarının geliştirilmesinde kilit noktadır (Erickson, 1993). Gelişimleri için yapılan açıklamalar doğrultusunda, matematik öğretmenlerinin; öğreteceği matematiğin içeriği, matematiksel hedeflere uygun öğretim yöntem ve teknikleri, materyalleri uygulama, değerlendirme yapma ile öğrencilerine empati yapmalarına yönelik eğitim almaları; gelişimlerini sağlamak üzere iyi öğretimi örnek alma ve etkin olmaları, matematiğe olumlu tutum geliştirmeleri gerektiği anlaşılmaktadır. Matematiği seven, temel anlamda kavramları iyi bilen öğretmenler; matematik öğretirken kendini rahat hissedebilecek ve öğrencilerin de matematiğe karşı olumlu tutum geliştirmelerine yardımcı olabilecektir (Doğan, 2000).

Etkili matematik öğretiminin gerçekleşebilmesi bağlamında öğretmen ve öğrencilere çeşitli roller düşmektedir. Bu bağlamda, NCTM (2000) raporuna göre, öğretmen; faydalı matematiksel işler yapmalı, matematiksel gücün gelişimini teşvik edici öğrenme ortamları yaratmalıdır. Öğretmenin rolü sorular ortaya koymak, dinlemek, istemek ve izlemek olmalıdır. Öğrencinin rolü etkin ve etkileşimli dinleme, cevap verme ama aynı zamanda sorgulama, keşfetme, tartışma olmalıdır. Öğrenciler teknolojiyi, modelleri, yazmayı, görselleri ve konuşmayı içerecek şekilde araç kullanmaya cesaretlendirilmelidir. Öğretmenler, süregelen öğretme ve öğrenmenin analiziyle meşgul olmalıdır (NCTM, 2000).

Matematiğin derinliği ve içeriği her okul ve yaş grubuna göre değişiyor olmasına karşın, matematik eğitiminde öğrencinin; matematiksel problemleri çözebilmesi, matematiğin değerini öğrenmesi, matematiksel iletişimi öğrenmesi ve kendine güvenmesi gibi erişilmesi gereken temel ölçütler bulunmaktadır (NCTM, 1989; akt. Ersoy, 1997). Diğer taraftan, öğrencilerin matematik öğrenmeye ilişkin bildiklerinin çoğu, matematik derslerine katılımlarından gelmektedir (Anderson, 2007). Öğrenciler eğlenceli, canlı bir ortamda düşüncelerini korkusuzca söyleyebilmelidir (Umay, 1996). Gee (2001) ve Wenger (1998) için matematiği öğrenen öğrencinin hayal gücünün gelişmiş olması ve işbirliği yapma yönleri de bulunmaktadır (akt. Anderson, 2007). Bunlarla birlikte matematik programında da matematiği öğrenen öğrencilerin nasıl bireyler olmaları gerektiği açıklanmaktadır. Matematik dersi öğretim programına göre öğrencilerin; matematik okuryazarlık becerileri gelişmiş, matematiksel kavramları anlayabilen ve günlük hayatında kullanabilen, problem çözebilen, insanlar ve nesneler arasındaki ilişkileri kurabilen, üstbilişsel bilgi ve becerileri gelişmiş, matematiğe yönelik olumlu tutum geliştirebilen, sistemli, sabırlı ve sorumluluk sahibi, araştırma yapabilen ve bilgi 
üretebilen, matematiğin sanat ve estetikle ilişkisini fark edebilen ve matematiğe değer evren bireyler olmaları amaçlanmaktadır (MEB, 2017).

Geleceğin öğretmenlerini yetiştiren yükseköğretim kurumlarında öğretmen adaylarının mesleklerini tanımalarını sağlamak ve öğrencilere ilişkin bakış açılarını geliştirmek gerekmektedir. Diğer taraftan McDiarmid (1990) öğretmen adaylarının bilişsel ve duyuşsal birikimlerinin bilinmesinin önemine vurgu yapmaktadır (akt. Baydar ve Bulut, 2002). Bu birikimler ise imaj kavramına vurgu yapmaktadır. Horowitz’e (1983) göre imaj birçok sanatçı ve bazı ruh bilimciler için zihinsel imgeler ile ilişkili olup, "görsel olarak duyulara ilişkin bir niteliğe sahip zihinsel içerikler" olarak ifade edilmektedir (Akt. Sam ve Ernest, 2008). Thompson'a (1996) göre ise imaj, bir zihinsel canlandırmadan daha fazlası olup kinestezi (fizyoloji), içalg1, koku, dokunma, tat, görme ve duymanın söz konusu olduğu yaşantılara dayalı kısımlardan oluşmaktadır. İmajlar aynı zamanda korkma, eğlenme gibi geçmişteki duyuşsal yaşantılara dayalı kısımları ve karar verme, anlam çıarma, hayal etme gibi geçmişteki bilişsel yaşantılara dayalı kısımları içermektedir. Kiren (1988) ile Kieren ve Pirie $(1990,1991)$ için hayal etme eylemi de imajlara ilişkin açıkça bilgi vermektedir (Akt. Thompson, 1996). Bu açıklamalar doğrultusunda imajın zihinde canlandırılan, hayal edilen, duyuşsal ve bilişsel yaşantıları içeren yönlerinin söz konusu olduğu söylenebilir.

İmajın; zihinsel temsili içeren bilişsel ve tutumu, duyguları, endişeyi, kaygıyı, hazzı, korkuyu içeren duyuşsal bileşeni bulunmaktadır. İmaj hem çizimle hem de cümlelerle açıklanabilmektedir (Sam, 1999). Farklı araç ve teknikler kullanılarak bireyin matematik hakkındaki düşüncelerini ortaya çıkarmaya yönelik olarak, belli bir kavram ya da konu hakkındaki imajları incelenebilir, bunu yansıtan çizimler yapmaları istenebilir. Böylece görülmesi istenenin ötesinde, bireylere göstermek istediklerini sunma fırsatı sağlanmış olur. Ürün kadar sürecin de değerlendirilmesi sağlanarak bireylerin üst düzey düşünme becerilerini, yaratıcılıklarını, bilişsel ve duyuşsal birikimlerini yansıtmalarına olanak sağlanmış olur (Korkmaz, 2004). Rogers (1992) insan aklının zihinsel imajları oluşturmadaki gücünün farkında olunmasını vurgulayarak, zihinsel bir yapı olan imajın yaratıcı fikirlere ve iletişimin farklı şekillerine ilham vermek için kullanılması gerektiğini belirtmektedir (akt. Sam ve Ernest, 2008). Bu araştırmada da ilköğretim matematik, fen bilgisi ve sınıf öğretmenliği alanlarında öğrenim görmekte olan öğretmen adaylarının matematik öğretmenine ve matematiği öğrenen öğrenciye yönelik öğretmen yetiştirme programlarına başladıklarında ve bu programı tamamladıklarında sahip oldukları imajlara ilişkin var olan durumun ortaya konması amaçlanmıştır.

Matematik öğretmeni ve matematiği öğrenen öğrenciye yönelik imajları için yapılan araştırmalar doğrultusunda; öğrenciler öğretmen merkezli öğretim yerine öğrenci merkezli öğretimi tercih ettiklerine (Gökçek ve Güneş, 2011) değinmiş, öğretmenlerini olumsuz nitelendirmelerle betimlerken, sahip olmak istedikleri öğretmenler için olumlu nitelendirmeler kullanmışlardır (Toluk- 
Uçar, Pişkin, Akkaş ve Taşçı, 2010). Öğretmen adayları için matematik öğretmeni ve matematiği öğrenen öğrenciye yönelik imajları için yapılan pek araştırmaya rastlanmazken, yapılan araştırmalarda ise ya programa başlamaları ve bitirmeleri arasındaki değişim bağlamında mesleklerine hazırlanmalarında programın olumlu etki yarattığı (Guillaume ve Kirtman, 2010) ya da öğretmen merkezli sınıf ortamlarının yansıtıldığı (Güven ve Karataş, 2004) belirtilmiştir. Bu araştırmada da matematik öğretmeni ve matematiği öğrenen öğrenciye yönelik öğretmen adaylarının bilişsel ve duyuşsal edinimleri için derinlemesine bir anlayış açığa çıkarılmaya çalışılmıştır. Öğretmen adaylarının matematik öğretmenine ve matematiği öğrenen öğrenciye yönelik imajlarının belirlenmesi öğretmen eğitiminin odaklanması gereken noktaları göstermesi ve öğretmen yetiştirme programının geliştirilmesi açısından önemlidir. Çünkü program geliştirilirken bireylerin ihtiyaçlarının belirlenmesi bağlamında öğretmen adaylarının ihtiyaçlarıyla ilgilenilmesi; hedeflerin yerindeliğinin belirlenmesi ve etkinliklerin planlanarak, öğretmen adaylarının sürece etkin bir şekilde katılmasını sağlamaktadır. Öğretmen adaylarının matematiği öğrenen öğrenciye ve matematik öğretmenine ilişkin bilişsel ve duyuşsal birikimlerinin; öğretmen olduklarında yapacaklarına ilişkin de fikir vererek, programın başında ve sonunda öğretecekleri matematiğe ilişkin anlayışlarını, matematiği öğrenen öğrencilere ilişkin bakış açılarını ve mesleklerini ne kadar tanıdıklarını anlamaya katkı sağlayacaktır. Bu bağlamda sunulan bu çalışma ile cevap aranan araştırma sorusu "temel eğitim düzeyinde matematik öğretiminden sorumlu ya da derslerinde matematiği kullanan hizmet öncesi sınıf eğitimi, fen bilgisi ve matematik öğretmenlerinin; bir matematik öğretmeni olarak kendilerine ve matematiği öğrenen öğrencilerine yönelik imajları nasıldır?" şeklindedir.

\section{Yöntem}

$\mathrm{Bu}$ araştırmanın yöntemi, bir grubun belirli özelliklerini ortaya koymak üzere verilerin toplanmasına dayanan tarama araştırmasıdır. Tarama araştırmalarında, geçmişte ya da halen var olan bir durum var olduğu şekliyle betimlenmeye çalışılmaktadır (Karasar, 2012). Bu araştırmada da öğretmen adaylarının bir matematik öğretmeni olarak kendilerine ve matematiği öğrenen öğrencilere yönelik imajları betimlenmeye çalışılmıştır.

\section{Çalışma Grubu}

Araştırmanın çalışma grubunu bir Yükseköğretim Kurumunun aynı öğretmen eğitimi programına devam eden 1. ve 4. Sınıf düzeyindeki ilköğretim matematik öğretmenliği (İMÖ), alanları gereği matematiği öğretmekle sorumlu olduğu için sinıf öğretmenliği (İSÖ) ve fen bilgisi öğretmenliği (FBÖ) öğretmen adayları oluşturmaktadır.

Araştırmanın çalışma grubu amaçlı örnekleme yoluyla belirlenmiştir. Çalışma grubunun belirlenmesinde üniversiteler belirlenirken üniversitenin akademik birimleri arasında eğitim fakültesi 
ile İSÖ, İMÖ ve FBÖ programlarının bulunması, araştırma izninin alınabilmesi, Türkçe eğitim verilmesi ve araştırmacının kolay ulaşabilmesi ölçütleri kullanılarak Ankara'daki devlet üniversitelerinden biri seçilmiştir. Tablo 1'de program, sınıf düzeyi ve cinsiyet değişkenine göre çalışma gurubu yer almaktadır.

Tablo 1. Program, Sınıf Düzeyi ve Cinsiyet Değişkenine Göre Çalışma Grubu

\begin{tabular}{|c|c|c|c|c|c|c|c|c|c|c|c|c|c|c|}
\hline \multirow{3}{*}{ Program } & \multicolumn{6}{|c|}{ Birinci sinıf } & \multicolumn{6}{|c|}{ Dördüncü sınıf } & \multirow{2}{*}{\multicolumn{2}{|c|}{ Toplam }} \\
\hline & \multicolumn{2}{|c|}{ Kadin } & \multicolumn{2}{|c|}{ Erkek } & \multicolumn{2}{|c|}{ Toplam } & \multicolumn{2}{|c|}{ Kadın } & \multicolumn{2}{|c|}{ Erkek } & \multicolumn{2}{|c|}{ Toplam } & & \\
\hline & $n$ & $\%$ & $N$ & $\%$ & $n$ & $\%$ & $N$ & $\%$ & $n$ & $\%$ & $n$ & $\%$ & $n$ & $\%$ \\
\hline İMÖ & 59 & 14 & 9 & 2 & 68 & 16 & 41 & 10 & 9 & 2 & 50 & 12 & 118 & 28 \\
\hline FBÖ & 78 & 18 & 12 & 3 & 90 & 21 & 40 & 10 & 11 & 2 & 51 & 12 & 141 & 33 \\
\hline İSÖ & 68 & 16 & 20 & 5 & 88 & 21 & 65 & 15 & 12 & 3 & 77 & 18 & 165 & 39 \\
\hline Toplam & 205 & 48 & 41 & 10 & 246 & 58 & 146 & 35 & 32 & 7 & 178 & 42 & 424 & 100 \\
\hline
\end{tabular}

Tablo 1'de görüldüğü üzere çalışmaya katılan 424 öğretmen adayının 118'i İMÖ (\%27.8), 141'i (\%33.3) FBÖ ve 165’i (\%38.9) İSÖ programına devam etmektedir. 246’sı birinci sınıf (\%58) 178'i (\%42) dördüncü sınıf öğrencileridir. Katılımcıların 351'i (\%82.7) kadın, 73’ü (\%17.3) erkektir. Dağılımları dikkate alındığında program ve sınıf düzeyindeki dağılımların yüzdesi yakın olmasına rağmen cinsiyet dağılımı açısından kadın öğretmen adaylarının sayısı erkek öğretmen adaylarının sayısından daha fazladır.

\section{Veri Toplama Aracı ve Verilerin Toplanması}

Araştırmada öğretmen adaylarının bir matematik öğretmeni olarak kendilerine ve matematiği öğrenen öğrenciye yönelik çizim yapmaları ve yaptıkları çizimlere ilişkin açı uçlu sorulara cevap vermeleri istenmiştir. Çizim testleri projektif (yansıtma) testleridir. Oluşturulan çizim formu için Thomas, Pedersen ve Finson (2001) tarafından tasarlanan "The Draw-A-Science-Teacher-Test Checklist (DASTT-C)" formunun ilk bölümünde yer alan ifadeler matematik öğretmeni ve matematik öğrenen öğrenciler olarak uyarlanmış ve kullanılmıştır. "Çalışan bir matematik öğretmeni olarak kendinizi çiziniz." ifadesi yoluyla öğretmen adaylarının çizim yapmaları ve çizimlerini tasvir etmeleri için “Öğretmen ne yapıyor? Öğrenciler ne yapıyor?" sorularına cevap vererek açıklamada bulunmaları sağlanmıştır. Çizimleri ve açıklamaları doğrultusunda öğretmen adaylarının hem matematik öğretmenine hem de matematiği öğrenen öğrenciye ilişkin imajlarının belirlenmesi amaçlanmıştır. Soruları beş ölçme ve değerlendirme uzmanı, beş program geliştirme uzmanı ve beş konu alanı uzmanı (beş lise matematik öğretmeninin ve üç öğretim elemanının) da uygun bulmuştur.

Veri toplama sürecinden önce uygulamanın yapılabilmesi için ilgili resmi kurumun Etik Komisyonu'ndan 21.07.2015 tarihli 35853172/433_2306 sayılı onay alınmıştır. Çizim formu; 2015-2016 akademik yılı güz dönemi başlangıcında, sınıf öğretmenliği, ilköğretim matematik ve fen bilgisi öğretmenliği birinci sınıf öğretmen adaylarına uygulanmıştır. Aynı form 2015-2016 akademik yılı bahar 
dönemi sonunda, sınıf öğretmenliği, ilköğretim matematik ve fen bilgisi öğretmenliği son sınıf öğretmen adaylarına uygulanmıştır. Uygulama ortalama olarak 20 dakika sürmüştür. Uygulamaların yapılabilmesi için; birinci sınıf düzeyindeki öğretmen adayları için derslerine giren üç öğretim elemanıyla iletişime geçilerek iki haftada uygulamalar tamamlanmıştır. Dördüncü sınıf düzeyindeki öğretmen adayları için dört öğretim elemanıyla iletişime geçilerek uygulamalar yine iki haftada tamamlanmıştır. Araştırmalar gönüllülük esası dikkate alınarak yürütülmüş̧ür.

\section{Verilerin Analizi}

Çizim formunda yer alan her açık uçlu soru için; verilen cevaplar yazıya dökülmüş, yazıya dökülen cevapların içerik analizi için ifadeler sınıflandırılarak kodlar oluşturulmuş, elde edilen kodlar temalar etrafında birleştirilmiş, boş bırakan öğretmen adayı olması durumunda, o öğretmen adayı ya da adayları ilgili soru için analiz dışında bırakılmıştır. Ayrıca matematik öğretmeni ve matematiği öğrenen öğrencilerin fiziksel özellikleri ve konumları, ortamda bulunan nesneler açılanmıştır.

Yapılan kodlamalar için uzman görüşleri arasındaki uyumu ortaya koymak üzere Miles ve Huberman'ın (1994) "güvenirlik=görüş birliği sayısı/(görüş birliği sayısı + görüş ayrılığ1 sayısı) formülü uygulanmıştır. Bu bağlamda her sınıf düzeyi ve programdan beşer öğretmen adayı olmak üzere toplam 30 öğretmen adayının çizimleri için araştırmacının yanı sıra bir uzman da kodlama yapmıştır. Eğitim Bilimleri alanında doktorasını tamamlamış olan uzman öncelikle imajlar konusunda eğitilmiş, birlikte örnek kodlamalar yapılmıştır. Ardından araştırmadaki kodlamaların iki uzman tarafından ayrı ayrı yapılması sağlanmıştır. Görüş birliği sağlanan 68 kod aynı kalmış, 7 kod revize edilmiş ve \%91 uzmanlar arası uyumla ilgili kodlara karar verilmiştir. \%90 ve üzeri Miles ve Huberman (1994) için kabul edilebilir bir değerdir. Veriler betimsel istatistik analizi olan yüzde hesabı kullanılarak raporlanmıştır.

\section{Bulgular}

Bu bölümde öğretmen adaylarının matematik öğretmenine ve matematiği öğrenen öğrenciye yönelik imajlarına ilişkin çizimler ve verilen cevaplar doğrultusunda bulgulara yer verilmiştir.

\section{Öğretmen Adaylarının Matematik Öğretmenine Yönelik İmajları}

Matematik öğretmenine yönelik imajları için öğretmen adaylarından; çizim yoluyla kendilerini bir matematik öğretmeni olarak hayal ettiklerinde, matematik öğretmeninin ne yaptığını belirtmeleri istenmiştir. Aşağıda sırasıyla hem çeşitli özellikler (cinsiyet, yüz ifadesi, konum, içerik) açısından hem de açık uçlu soruya verilen cevaplar doğrultusunda deşifre edilen imajlara, alıntı örneklerine, yüzde değerlerine ve çizimlere yönelik örneklere yer verilmiştir.

Tablo 2' de çeşitli özellikler (cinsiyet, yüz ifadesi, konum, içerik) açısından matematik öğretmeni çizimleri ele alınmıştır. 
Tablo 2. Çeşitli Özellikler Açısından Matematik Öğretmeni Çizimleri

\begin{tabular}{|c|c|c|}
\hline Özellik & & Yüzde \\
\hline \multirow[t]{2}{*}{ Cinsiyet } & Kadın & 83 \\
\hline & Erkek & 17 \\
\hline \multirow[t]{3}{*}{ Yüz ifadesi } & Güler yüzlü & 89,1 \\
\hline & Mutsuz & 3,8 \\
\hline & Belirsiz & 7,1 \\
\hline \multirow[t]{5}{*}{ Konum } & Ayakta & 61,3 \\
\hline & Oturan & 38,7 \\
\hline & Elinde kalem/ materyal tutan & 22,6 \\
\hline & Elindeki kalem ya da çubukla yazı tahtasını gösteren & 11,6 \\
\hline & Yazı tahtasının önünde ya da yanında duran & 23,1 \\
\hline \multirow[t]{6}{*}{ İçerik bilgisi } & Boş yazı tahtası & 10,1 \\
\hline & Yazı tahtalarında yazılı olarak ders ya da konu bilgisi & 6,4 \\
\hline & Dört işlem ifadesi ya da soruları & 10,8 \\
\hline & Sayma sayıları & 4 \\
\hline & Denklem ifadesi ya da soru & 9,2 \\
\hline & Geometrik şekiller & 2,4 \\
\hline
\end{tabular}

Tablo 2 incelendiğinde çizim yoluyla kendilerini matematik öğretmeni olarak hayal ettiklerinde yaptıkları çizimlerde öğretmen adayları, çoğunlukla kadın öğretmen (\%83) çizmişlerdir. Ardından erkek öğretmenler (\%17) gelmiştir. Çalışma grubundaki cinsiyet dağılımı düşünüldügünde kadın öğretmen adaylarının ve erkek öğretmen adaylarının kendi cinsiyet gruplarını yansıttıkları gözlenmektedir. Çizimlerde öğretmen adaylarının matematik öğretmenini çoğunlukla diğer varlıklarla orantılı olarak çizmelerine karşın, oldukça büyük $(\% 8,2)$ çizdikleri resimlerin varlığı da gözlenmektedir. Öğretmen adaylarının çizimlerinde bir matematik öğretmeni olarak kendilerini çoğunlukla yüz ifadeleri açısından güler yüzlü $(\% 89,1)$ çizdikleri gözlenmektedir. Öğretmen adaylarının sınıfta bir matematik öğretmeni olarak kendilerini hayal ettiklerinde çizimlerindeki öğretmenlerin konum olarak \%61,3'ünün ayakta ve geri kalan \%38,7'sinin ise oturduğu belirlenmiştir. Çizimlerde ders içerikleri açısından yansıtılan bazı bulgular da tespit edilmiştir. Örneğin ders içeriklerine ilişkin olarak boş yazı tahtalarının olmasının yanı sıra $(\% 10,1)$, yazı tahtalarında ders ya da konu bilgisinin $(\% 6,4)$, dört işlem ifadesi ya da sorularının $(\% 10,8)$ yansıtıldığı gözlenmiştir.

Öğretmen adaylarının çizim yoluyla kendilerini matematik öğretmeni olarak hayal ettiklerinde; bu öğretmenin yaptıklarına ilişkin olarak ders anlattığını, derse giriş/çıkış yaptığını, derse katılımı sağladı̆̆ını, derse yönelik olumlu duyguya sahip olunmasını să̆ladığını, olumlu duyguya sahip olduğunu, olumsuz duyguya sahip olduğunu, ögrencileriyle iletişim kurdŭ̆unu ve sınav yaptığını ifade ettikleri gözlenmektedir. Tablo 3'te çizimlerde matematik öğretmeninin yaptıklarına ilişkin kodlar ve alıntılar yer almaktadır. 
Tablo 3. Matematik Öğretmeninin Yaptıklarına Yönelik Kodlar ve Alıntılar

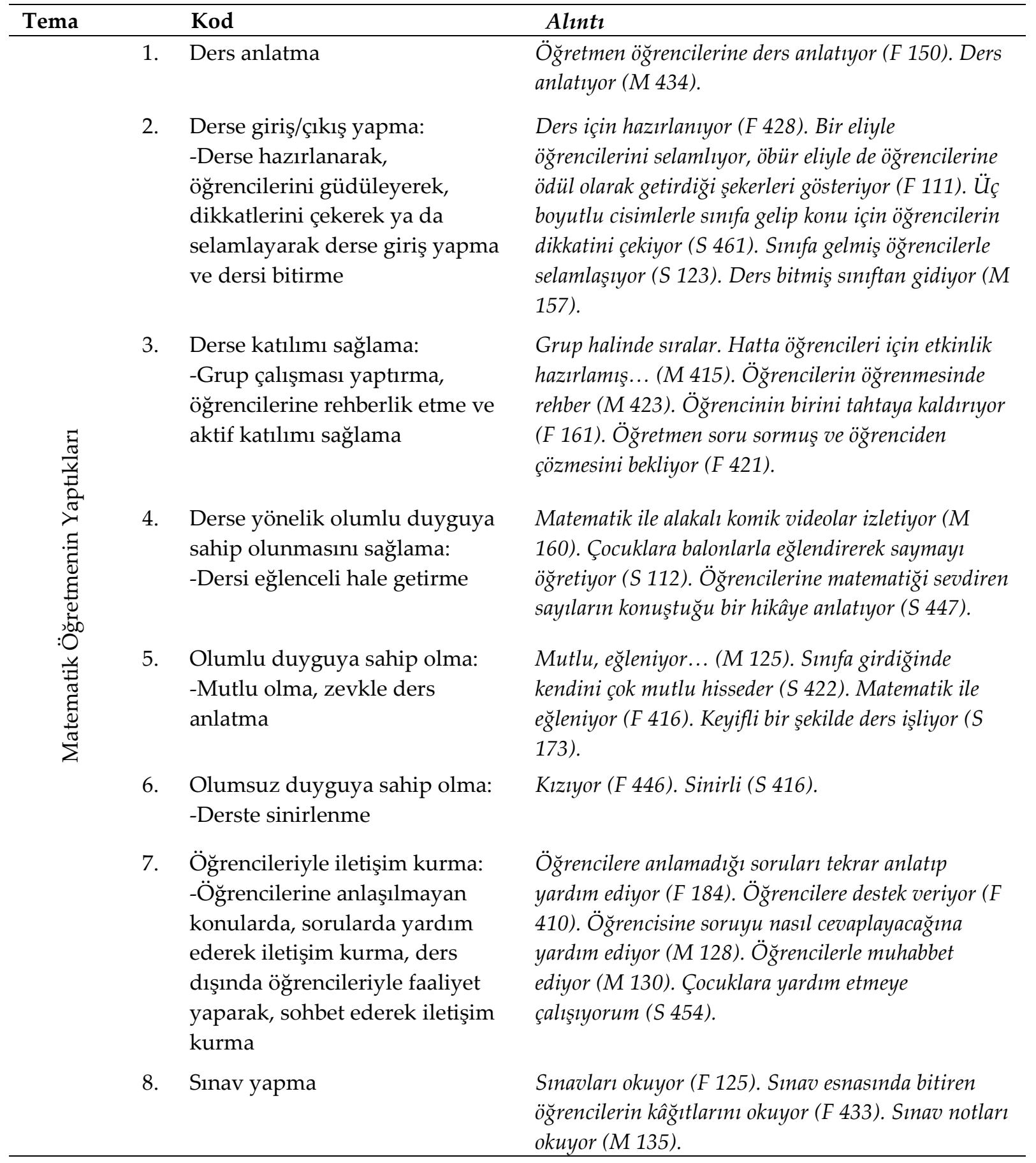

Tablo 3'te görüldüğü üzere örneğin çizimlerinde olumlu duyguya sahip olduklarını ifade eden öğretmen adaylarının mutlu olduklarını, zevkle ders anlattıklarını belirttikleri gözlenmektedir. Bu bağlamda bazı öğretmen adayı görüşleri şöyledir: “Mutlu, eğleniyor... (M 125). Sınıfa girdiğinde kendini çok mutlu hisseder (S 422). Matematik ile eğleniyor (F 416). Keyifli bir şekilde ders işliyor (S 173)."

Tablo 4'te öğretmen adaylarının tamamı, program türleri ve sınıf düzeyi için öğretmen adaylarının çizimlerinde matematik öğretmeninin ne yaptığı açıklanmıştır. 
Tablo 4. Program Türü ve Sınıf Düzeyine Göre Matematik Öğretmeninin Yaptıkları

\begin{tabular}{|c|c|c|c|c|c|c|c|c|}
\hline \multirow{2}{*}{ Tema } & & \multirow[b]{2}{*}{ Kod } & \multicolumn{6}{|c|}{ Yüzde } \\
\hline & & & $\begin{array}{l}\text { Öğretmen } \\
\text { Adaylarının } \\
\text { Tamamı } \\
\end{array}$ & İMÖ & FBÖ & ÍSÖ & $\begin{array}{l}\text { Birinci } \\
\text { Sinif }\end{array}$ & $\begin{array}{l}\text { Dördüncü } \\
\text { Sınıf }\end{array}$ \\
\hline \multirow{8}{*}{ 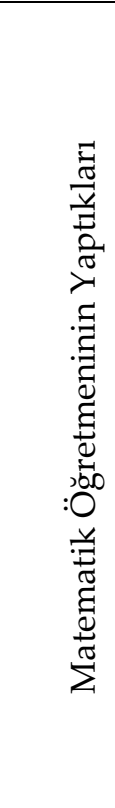 } & 1. & Ders anlatma & 35,4 & 35,6 & 37,6 & 33,3 & 45,1 & 21,9 \\
\hline & 2. & $\begin{array}{l}\text { Derse katılımı } \\
\text { sağlama }\end{array}$ & 17,9 & 24,6 & 11,3 & 18,8 & 15,9 & 20,8 \\
\hline & 3. & $\begin{array}{l}\text { Derse yönelik } \\
\text { olumlu duyguya } \\
\text { sahip olunmasını } \\
\text { sağlama }\end{array}$ & 13,7 & 11 & 11,3 & 17,6 & 8,9 & 20,2 \\
\hline & 4. & $\begin{array}{l}\text { Derse giriş/çııış } \\
\text { yapma }\end{array}$ & 10,1 & 5,9 & 10,6 & 12,7 & 8,1 & 12,9 \\
\hline & 5. & $\begin{array}{l}\text { Öğrencileriyle } \\
\text { iletişim kurma }\end{array}$ & 8 & 12,7 & 9,2 & 3,6 & 8,9 & 6,7 \\
\hline & 6. & $\begin{array}{l}\text { Olumlu duyguya } \\
\text { sahip olma }\end{array}$ & 4,7 & 2,5 & 5,7 & 5,5 & 4,1 & 5,6 \\
\hline & 7. & $\begin{array}{l}\text { Olumsuz } \\
\text { duyguya sahip } \\
\text { olma }\end{array}$ & 1,2 & - & 1,4 & 1,8 & - & 2,8 \\
\hline & 8. & Sinav yapma & 1,2 & 1,7 & 2,1 & - & 1,2 & 1,1 \\
\hline
\end{tabular}

Tablo 4'e göre hem öğretmen adaylarının tamamı (\%35,4), hem program türleri (İMÖ \%35,6; FBÖ \%37,6; İSÖ \%33,3) hem de sınıf düzeyi (birinci sınıf \%41,5; dördüncü sınıf \%21,9) bağlamında matematik öğretmenleri en çok, ders anlatmaktadır. En az ise hem öğretmen adaylarının tamamı (\%1,2\%1,2), hem program türleri (İMÖ \%1,7-\%0; FBÖ \%2,1-\%1,4; İSÖ \%1,2-\%0) hem de sınıf düzeyleri (birinci sınıf \%1,2-\%0; dördüncü sınıf \%1,1-\%2,8) bağlamında matematik öğretmenleri sınav yapmakta ve olumsuz duyguya sahip olmaktadır. Ayrıca öğretmen adayları aynı çizimde olmak üzere birden fazla görüş de bildirmiştir. Bu durum aşağıda sırasıyla öğretmen adaylarının tamamı, program türleri ve sınıf düzeyleri için ayrı ayrı açıklanmaktadır;

(a) Öğretmen adaylarının tamamı bağlamında ders anlatmanın yanı sıra; derse katılımı sağladığına $(\% 0,7)$, öğrencileriyle iletişim kurduğuna $(\% 0,5)$, derse giriş/çıkış yaptığına $(\% 0,2)$, derse giriş/çıkış yapıp derse katılımı sağladığına $(\% 0,2)$ da nadiren değindikleri anlaşılmaktadır. Derse giriş/çıkış yapmasının yanı sıra derse katılımı sağladığına (\%0,2), derse yönelik olumlu duyguya sahip olunmasını sağladığına $(\% 0,2)$, derse katılımı sağlayıp öğrencileriyle iletişim kurduğuna $(\% 0,2)$ da nadiren değindikleri gözlenmektedir. Derse katılımı sağlamasının yanı sıra; olumsuz duyguya sahip olmasına $(\% 0,2)$ da nadiren değindikleri anlaşılmaktadır. Olumlu duyguya sahip olmasının yanı sıra; öğrencileriyle iletişim kurduğuna $(\% 0,2)$ da nadiren değindikleri gözlenmektedir. \%5'inin hiç görüş bildirmedikleri de anlaşılmaktadır. 
(b) IMÖ öğretmen adayları bağlamında ders anlatmanın yanı sıra; derse katılımı sağladığına $(\% 0,8)$ ve derse giriş/çıkış yapıp derse katılımı sağladığına $(\% 0,8)$ da nadiren değindikleri anlaşılmaktadır. Derse giriş/çıkış yapmasının yanı sıra derse katılımı sağlayıp öğrencileriyle iletişım kurduğuna $(\% 0,8)$ da nadiren değindikleri gözlenmektedir. \%3,4'ünün de hiç görüş bildirmedikleri anlaşılmaktadır.

(c) FBÖ öğretmen adayları bağlamında ders anlatmanın yanı sıra; öğrencileriyle iletişim kurduğuna $(\% 1,4)$, derse katılımı sağladığına $(\% 0,7)$, derse giriş/çıkış yaptığına $(\% 0,7)$ da nadiren değindikleri anlaşılmaktadır. Derse giriş/çıkış yapmasının yanı sıra derse katılımı sağladığına $(\% 0,7)$, derse yönelik olumlu duyguya sahip olunmasını sağladı̆̆ına $(\% 0,7)$ da nadiren değindikleri gözlenmektedir. Olumlu duyguya sahip olmasının yanı sıra; öğrencileriyle iletişim kurduğuna $(\% 0,7)$ da nadiren değindikleri anlaşılmaktadır. \%5,7'sinin de hiç görüş bildirmedikleri gözlenmektedir.

(d) İSÖ öğretmen adayları bağlamında ders anlatmanın yanı sıra; derse katılımı sağladığına (\%0,6) da nadiren değindikleri anlaşılmaktadır. Derse katılımı sağlamasının yanı sıra; olumsuz duyguya sahip olmasına $(\% 0,6)$ da nadiren değindikleri gözlenmektedir. \%5,5'inin de hiç görüş bildirmedikleri anlaşılmaktadır.

(e) Birinci sımıf düzeyindeki öğretmen adayları bağlamında ders anlatmanın yanı sıra; derse katılımı sağladığına $(\% 1,2)$ ve öğrencileriyle iletişim kurduğuna $(\% 0,4)$ da nadiren değindikleri anlaşılmaktadır. Derse giriş/çıkış yapmasının yanı sıra derse katılımı sağladığına $(\% 0,4)$, derse yönelik olumlu duyguya sahip olunmasını sağladığına $(\% 0,4)$ da nadiren değindikleri gözlenmektedir. Derse katılımı sağlamasının yanı sıra; olumsuz duyguya sahip olmasına $(\% 0,4)$ de nadiren değindikleri anlaşılmaktadır. Birinci sınıf düzeyindeki öğretmen adaylarının \%4,9’unun da hiç görüş bildirmedikleri gözlenmektedir.

(f) Dördüncü sınıf düzeyindeki öğretmen adayları bağlamında ders anlatmanın yanı sıra; öğrencileriyle iletişim kurduğuna (\%0,6), derse giriş/çıkış yaptığına $(\% 0,6)$, derse giriş//̧̧ıış yapıp derse katılımı sağladığına $(\% 0,6)$ da nadiren değindikleri gözlenmektedir. Derse giriş/çıkış yapmasının yanı sıra derse katılımı sağlayıp öğrencileriyle iletişim kurduğuna $(\% 0,6)$ da nadiren değindikleri anlaşılmaktadır. Olumlu duyguya sahip olmasının yanı sıra; öğrencileriyle iletişim kurduğuna $(\% 0,6)$ da nadiren değindikleri gözlenmektedir. Dördüncü sınıf düzeyindeki öğretmen adaylarının da \%5,1'inin hiç görüş bildirmedikleri gözlenmektedir. 
Şekil 1'de matematik öğretmeni için çizim örnekleri yer almaktadır.

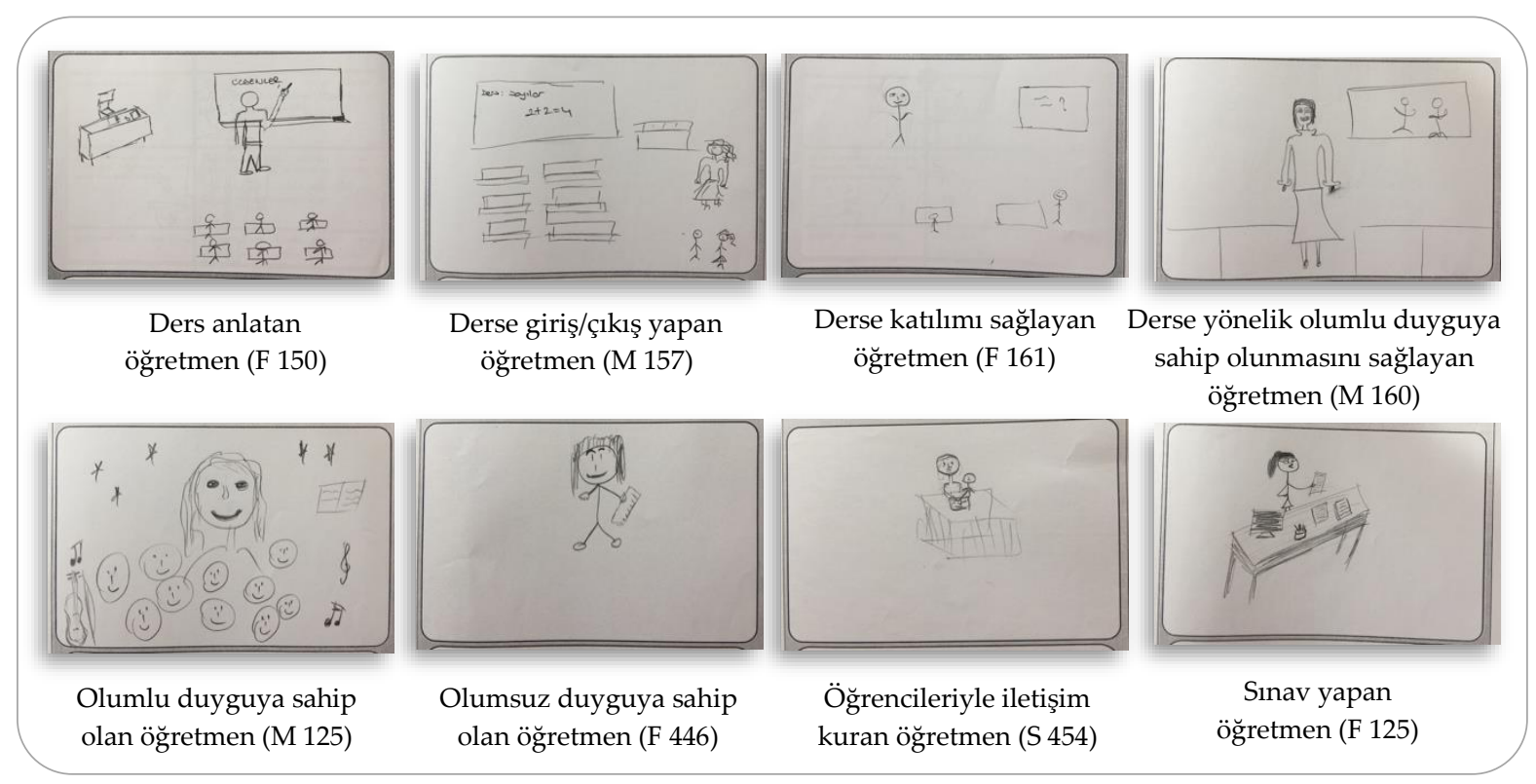

Şekil 1. Matematik öğretmeni için çizim örnekleri

\section{Öğretmen Adaylarının Matematiği Öğrenen Öğrenciye Yönelik İmajları}

Öğrenciye yönelik imajları için öğretmen adaylarından; çizim yoluyla kendilerini matematik öğretmeni olarak hayal ettiklerinde, çizimlerinde öğrencilerin ne yaptıklarını belirtmeleri istenmiştir. Aşağıda sırasıyla hem çeşitli özellikler (konum, sıra, etkinlik) açısından hem de açık uçlu soruya verilen cevaplar doğrultusunda deşifre edilen imajlara, alıntı örneklerine, yüzde değerlerine ve çizimlere yönelik örneklere yer verilmiştir.

Tablo 5'te çeşitli özellikler (konum, sıra, etkinlik) açısından matematik öğretmeni çizimleri ele alınmıştır.

Tablo 5. Çeşitli Özellikler Açısından Matematiği Öğrenen Öğrenci Çizimleri

\begin{tabular}{lll}
\hline Özellik & & Yüzde \\
\hline Konum & Sirada oturan & 75,7 \\
& Ayaktan olan & 21,5 \\
& Masada olan & 2,8 \\
& Öğretmenin yanında olan & 4 \\
\multirow{3}{*}{ Sıra } & Yazı tahtasının önünde ya da yanında olan & 3,1 \\
& Önlü arkalı tekli ya da çiftli sıra & 88,9 \\
& Tekli ya da çiftli yan yana sıra & 9,4 \\
& “U” şeklinde sıra & 1,7 \\
& Nesne taşıyan sıra & 6,1 \\
& Parmak kaldıran & 1,7 \\
& Dersle ilgilenmeyen & 1,7 \\
& Yazı tahtasına yazı yazan & 1 \\
\hline
\end{tabular}


Tablo 5'e göre öğretmen adaylarının çizim yoluyla kendilerini matematik öğretmeni olarak hayal ettiklerinde yaptıkları çizimlerde; öğrencilerin çoğunlukla sıralarında oturduğu $(\% 75,7)$ gözlenmektedir. Öğretmen adaylarının çizimlerinde; sırada oturan öğrencilerin çoğunlukla önlü arkalı tekli ya da çiftli $(\% 88,9)$ şekilde dizildikleri tespit edilmiştir. Parmak kaldıran $(\% 1,7)$, dersle ilgilenmeyen $(\% 1,7)$ ya da yazı tahtasına yazı yazan (\%1) öğrencilerin de olduğu gözlenmiştir.

Öğretmen adaylarının çizim yoluyla kendilerini matematik öğretmeni olarak hayal ettiklerinde; yaptıkları çizimlerde öğrencilerin ders dinlediğini, derse giriş/_̧̧ııı̧ yaptığını, derse ilgisiz olduğunu, derse katıldığını, derse yönelik olumlu duyguya sahip olduklarını, öğretmenleriyle iletişim kurduklarını ve sınav olduklarını ifade ettikleri gözlenmektedir. Tablo 6'da çizimlerde matematiği öğrenen öğrencinin yaptıklarına ilişkin kodlar ve alıntılar yer almaktadır.

Tablo 6. Matematiği Öğrenen Öğrencinin Yaptıklarına Yönelik Kodlar ve Alıntılar

\begin{tabular}{|c|c|c|}
\hline Tema & Kod & Alintr \\
\hline 1. & Ders dinleme & $\begin{array}{l}\text { Dersi dinliyor (S 131). Öğrenciler dersi dinliyor (M } \\
\text { 420). Dinliyor (F 438). }\end{array}$ \\
\hline 2. & $\begin{array}{l}\text { Derse giriş/çıkış yapma: } \\
\text { - Dersi bekleme ya da ders } \\
\text { bitimi sınıftan ayrılma }\end{array}$ & $\begin{array}{l}\text { Ya sıralara geçmiş oturuyor ya da daha yeni sinıfa } \\
\text { giriyorlar (F 119). Straya oturacaklar (M 116). Ders } \\
\text { bitmiş sınıftan gidiyor (M 157). Teneffüsteler, } \\
\text { birazdan zil çalacak (M 426). }\end{array}$ \\
\hline
\end{tabular}

3. Derse ilgisiz olma: - Dersten kopma ve olumsuz davranışlar sergileme

Bağırıyorlar (S 121). Kendi aralarında konuşuyorlar (F 423). Arkada sıkıntıdan kâğıt savaşı yapıyor (S 163). Kendi hallerinde takulyyorlar (F 143).

4. Derse katılma: - Grup çalışması yapma, soru çözmesi, derse aktif katılma

Grup çalışması yapıyorlar (M 419). Soruyu çözmeye çalışıyor (M 117). Parmak kaldırarak derse aktif katılımı sağlıyorlar (M 407). Öğretmenle yaptıkları konuşmada fikirlerini sunuyorlar (S 184). Derse katiliyor (S 463).

5. Derse yönelik olumlu duyguya Oturup neşeli şekilde öğretmenlerini dinliyorlar ( $M$ sahip olma: - Dersi sevme, sinifta mutlu olma ve eğlenme 133). Öğrenciler mutlu (S 161). Öğrenciler eğleniyor (F 437). Ĕ̆glenerek öğrenmenin tadını çıkartıyorlar (M 160).

6. Öğretmeniyle iletişim kurma: Öğrenciler straya girmiş soru soruyor (F 106). Soru Öğretmeninden yardım isteme ya da ders dişında öğretmeniyle faaliyet yapmak, sohbet etmek üzere iletişim kurma

7. Sinav olma Sinav oluyorlar (F 139). Öğrenciler sinavda (F 433).

Tablo 6'da görüldüğü üzere örneğin öğretmen adaylarının çizimlerinde öğrencilerin derse yönelik olumlu duyguya sahip oldukların belirtmeleri bağlamında; öğrencilerin dersi sevdiklerini, 
sınıfta mutlu olduklarını ve eğlendiklerini ifade ettikleri gözlenmektedir. Bu ifadelere ilişkin öğretmen adaylarının görüşlerini yansıtan örnekler şunlardır: “Oturup neşeli şekilde öğretmenlerini dinliyorlar (M 133). Öğrenciler mutlu (S 161). Öğrenciler eğleniyor (F 437). Ĕ̆glenerek ö̆grenmenin tadını çıkartıyorlar (M 160)."

Tablo 7'de öğretmen adaylarının tamamı, program türü ve sınıf düzeyi için öğretmen adaylarının çizimlerinde matematiği öğrenen öğrencilerin ne yaptığı açıklanmıştır.

Tablo 7. Program Türü ve Sınıf Düzeyine Göre Matematiği Öğrenen Öğrencinin Yaptıkları

\begin{tabular}{|c|c|c|c|c|c|c|c|c|}
\hline \multirow[b]{2}{*}{ Tema } & & \multirow[b]{2}{*}{ Kod } & \multicolumn{6}{|c|}{ Yüzde } \\
\hline & & & $\begin{array}{l}\text { Öğretmen } \\
\text { Adaylarının } \\
\text { Tamamı } \\
\end{array}$ & İMÖ & FBÖ & ISÖ & $\begin{array}{l}\text { Birinci } \\
\text { Sinif }\end{array}$ & $\begin{array}{l}\text { Dördüncü } \\
\text { Sınıf }\end{array}$ \\
\hline \multirow{7}{*}{ 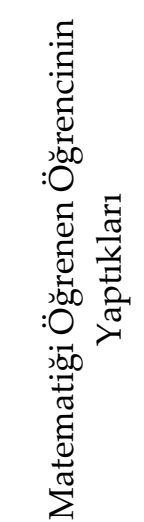 } & 1. & Ders dinleme & 32,8 & 38,1 & 29,8 & 31,5 & 41,5 & 20,8 \\
\hline & 2. & Derse katılma & 14,2 & 18,6 & 7,1 & 17 & 10,2 & 19,7 \\
\hline & 3. & $\begin{array}{l}\text { Derse yönelik } \\
\text { olumlu duyguya } \\
\text { sahip olma }\end{array}$ & 19,3 & 16,1 & 17 & 23,6 & 13 & 28,1 \\
\hline & 4. & $\begin{array}{l}\text { Derse giriş/çıkış } \\
\text { yapma }\end{array}$ & 4,7 & 0,8 & 8,5 & 2,4 & 4,9 & 4,5 \\
\hline & 5. & $\begin{array}{l}\text { Öğretmeniyle } \\
\text { iletişim kurma }\end{array}$ & 9,4 & 11,9 & 12,1 & 5,5 & 8,9 & 10,1 \\
\hline & 6. & Derse ilgisiz olma & 3,8 & 0,8 & 4,3 & 5,5 & 4,5 & 2,8 \\
\hline & 7. & Sinav olma & 1,2 & 0,8 & 2,8 & - & 1,2 & 1,1 \\
\hline
\end{tabular}

Tablo 7'ye göre hem öğretmen adaylarının tamamı (\%32,8), hem program türleri (İMÖ \%38,1; FBÖ \%29,8; İSÖ \%31,5) hem de birinci sınıf düzeyi $(\% 41,5)$ bağlamında matematiği öğrenen öğrenciler en çok ders dinlemektedir. Dördüncü sınıf düzeyindeki öğretmen adayları $(\% 28,1)$ için ise en çok derse yönelik olumlu duyguya sahip olmak ön plana çıkmıştır. En az ise hem öğretmen adaylarının tamamı (\%1,2-\%3,8), hem program türlerinden İMÖ $(\% 0,8-\% 0,8)$ ve FBÖ $(\% 2,8-\% 4,3)$ hem de sinıf düzeyleri (birinci sınıf \%1,2-\%4,5; dördüncü sınıf \%1,1-\%2,8) bağlamında matematiği öğrenen öğrenciler sınav olmakta ya da derse ilgisiz kalmaktadır. İMÖ öğretmen adayları sınav olma ve derse ilgisiz kalma gibi derse giriş/çıkış yapma $(\% 0,8)$ eylemini de en az belirtmişlerdir. İSÖ alanındaki öğretmen adayları ise en az sınıflamasında sınav olmaya (\%0) değinmezken, derse giriş/çıkış yapmayı $(\% 2,4)$ ifade etmişlerdir. Ayrıca öğretmen adayları aynı çizimde olmak üzere birden fazla görüş de bildirmiştir. Bu durum aşağıda sırasıyla öğretmen adaylarının tamamı, program türleri ve sınıf düzeyleri için ayrı ayrı açılanmaktadır;

(a) Öğretmen adaylarının tamamı bağlamında ders dinlemelerinin yanı sıra; olumlu duyguya sahip olduklarına $(\% 2,1)$, öğretmenleriyle iletişim kurduklarına $(\% 0,9)$, derse katıldıklarına $(\% 0,5)$, derse ilgisiz olduklarına $(\% 0,5)$, derse katılıp olumlu duyguya sahip olduklarına $(\% 0,2)$ ya da derse katılıp öğretmenleriyle iletişim kurduklarına $(\% 0,2)$ da nadiren değindikleri anlaşılmaktadır. Derse giriş/çıkış 
yapmalarının yanı sıra öğretmenleriyle iletişim kurduklarına $(\% 0,5)$ da nadiren değindikleri gözlenmektedir. Derse katılmanın yanı sıra; olumlu duyguya sahip olduklarına $(\% 0,7)$, derse ilgisiz olduklarına $(\% 0,2)$ ya da öğretmenleriyle iletişim kurduklarına $(\% 0,2)$ da nadiren değindikleri anlaşılmaktadır. Derse ilgisiz olmalarının yanı sıra; öğretmenleriyle iletişim kurduklarına $(\% 0,7)$ ya da olumlu duyguya sahip olduklarına $(\% 0,2)$ da nadiren değindikleri gözlenmektedir. \%3,8'inin hiç görüş bildirmedikleri, \%3,8'inin de çizimlerinde öğrenciye hiç yer vermediği gözlenmektedir.

(b) IMÖ öğretmen adayları bağlamında ders dinlemelerinin yanı sıra; olumlu duyguya sahip olduklarına (\%1,7), öğretmenleriyle iletişim kurduklarına (\%0,8), derse katılıp olumlu duyguya sahip olduklarına $(\% 0,8)$ ya da derse katılıp öğretmenleriyle iletişim kurduklarına $(\% 0,8)$ da nadiren değindikleri anlaşılmaktadır. Derse katılmanın yanı sıra; olumlu duyguya sahip olduklarına $(\% 0,8)$, derse ilgisiz olduklarına $(\% 0,8)$ ya da öğretmenleriyle iletişim kurduklarına $(\% 0,8)$ da nadiren değindikleri anlaşılmaktadır. \%3,4'ünün de hiç görüş bildirmedikleri gözlenmektedir.

(c) FBÖ öğretmen adayları bağlamında ders dinlemelerinin yanı sıra; olumlu duyguya sahip olduklarına $(\% 3,5)$, derse ilgisiz olduklarına $(\% 1,4)$, öğretmenleriyle iletişim kurduklarına $(\% 0,7)$ ya da derse katıldıklarına $(\% 0,7)$ da nadiren değindikleri anlaşılmaktadır. Derse giriş/çıkış yapmalarının yanı sıra öğretmenleriyle iletişim kurduklarına $(\% 1,4)$ da nadiren değindikleri gözlenmektedir. Derse katılmanın yanı sıra; olumlu duyguya sahip olduklarına $(\% 0,7)$ da nadiren değindikleri anlaşılmaktadır. Derse ilgisiz olmalarının yanı sıra; öğretmenleriyle iletişim kurduklarına $(\% 0,7)$ ya da olumlu duyguya sahip olduklarına $(\% 0,7)$ da nadiren değindikleri gözlenmektedir. $\% 2,8^{\prime}$ inin hiç görüş bildirmedikleri, $\% 5,7^{\prime}$ sinin de çizimlerinde öğrenciye hiç yer vermediği anlaşılmaktadır.

(d) İSÖ ögrretmen adayları bağlamında ders dinlemelerinin yanı sıra; olumlu duyguya sahip olduklarına $(\% 1,2)$, öğretmenleriyle iletişim kurduklarına $(\% 1,2)$ ya da derse katıldıklarına $(\% 0,6)$ da nadiren değindikleri anlaşılmaktadır. Derse katılmanın yanı sıra; olumlu duyguya sahip olduklarına $(\% 0,6)$ da nadiren değindikleri gözlenmektedir. Derse ilgisiz olmalarının yanı sıra; öğretmenleriyle iletişim kurduklarına $(\% 1,2)$ da nadiren değindikleri anlaşılmaktadır. \%4,8'inin hiç görüş bildirmedikleri, \%4,8'inin de çizimlerinde öğrenciye hiç yer vermediği gözlenmektedir.

(e) Birinci sını düzeyindeki öğretmen adayları bağlamında ders dinlemelerinin yanı sıra; olumlu duyguya sahip olduklarına (\%2) öğretmenleriyle iletişim kurduklarına $(\% 1,6)$, derse katıldıklarına $(\% 0,8)$ ya da derse ilgisiz olduklarına $(\% 0,8)$ da nadiren değindikleri anlaşılmaktadır. Derse giriş/çıkış yapmalarının yanı sıra öğretmenleriyle iletişim kurduklarına $(\% 0,8)$ da nadiren değindikleri gözlenmektedir. Derse katılmanın yanı sıra; olumlu duyguya sahip olduklarına $(\% 0,4)$ ya da derse ilgisiz olduklarına $(\% 0,4)$ da nadiren değindikleri anlaşılmaktadır. Derse ilgisiz olmalarının yanı sıra; öğretmenleriyle iletişim kurduklarına $(\% 1,2)$ ya da olumlu duyguya sahip olduklarına $(\% 0,4)$ da nadiren 
değindikleri gözlenmektedir. \%4,5'inin hiç görüş bildirmedikleri, \%2,8'inin de çizimlerinde öğrenciye hiç yer vermediği gözlenmektedir.

(f) Dördüncü sımı düzeyindeki öğretmen adayları bağlamında ders dinlemelerinin yanı sıra; olumlu duyguya sahip olduklarına $(\% 2,2)$, derse katılıp olumlu duyguya sahip olduklarına $(\% 0,6)$ ya da derse katılıp öğretmenleriyle iletişim kurduklarına $(\% 0,6)$ da nadiren değindikleri anlaşılmaktadır. Derse katılmanın yanı sıra; olumlu duyguya sahip olduklarına $(\% 1,1)$ ya da öğretmenleriyle iletişim kurduklarına $(\% 0,6)$ da nadiren değindikleri gözlenmektedir. \%2,8'inin hiç görüş bildirmedikleri, \%5,1'inin ise çizimlerinde öğrenciye hiç yer vermediği gözlenmektedir. Şekil 2'de matematiği öğrenen öğrenci için çizim örnekleri yer almaktadır.

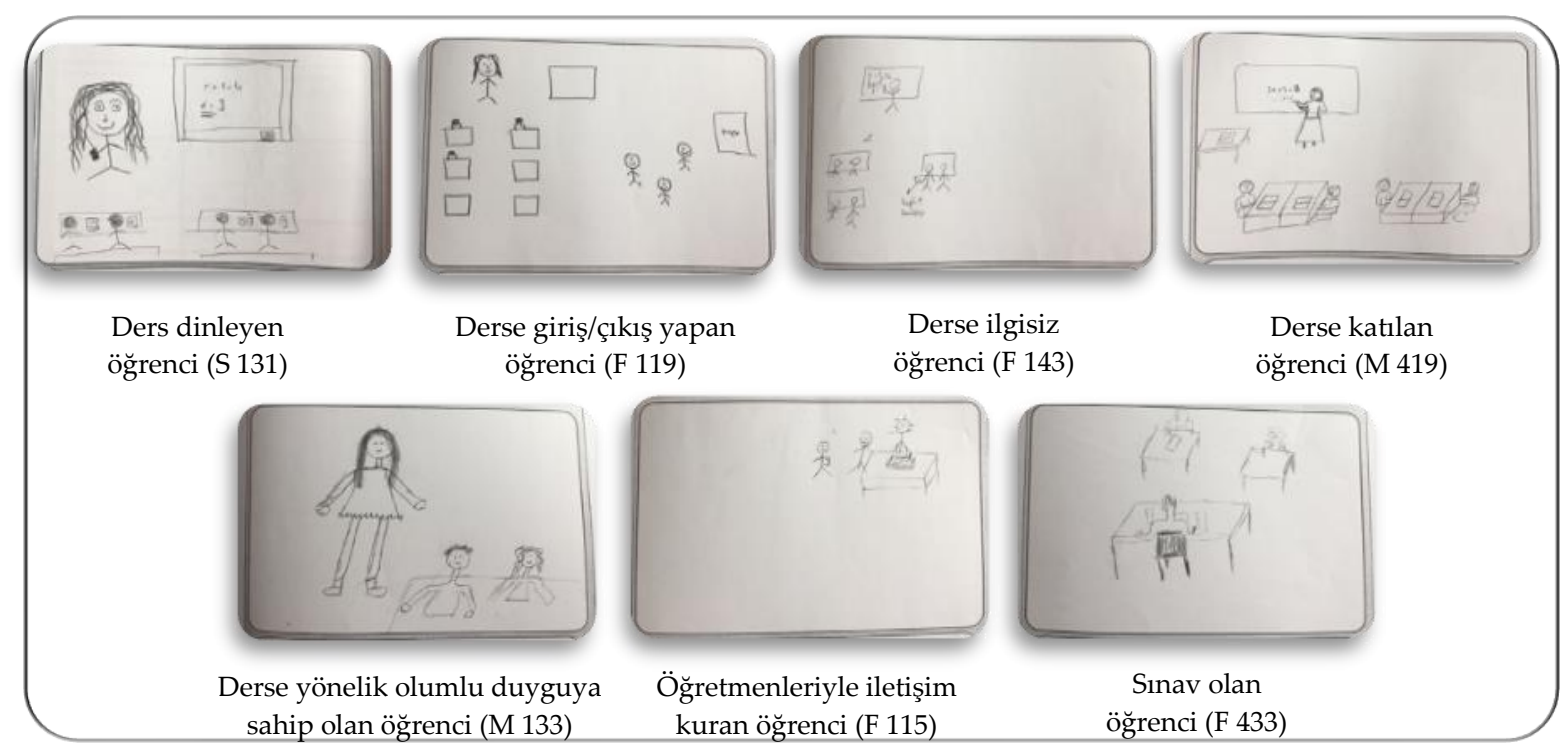

Şekil 2. Matematiği öğrenen öğrenci için çizim örnekleri

\section{Sonuç ve Öneriler}

Hizmet öncesi öğretmen adaylarının bir matematik öğretmeni olarak kendilerine ve matematik öğrenen öğrencilere yönelik imajlarının belirlenmesi amacıyla yürütülen bu çalışmadan öğretmen imajlarına ilişkin elde edilen bulgular şu şekilde özetlenebilir: Öğretmen adayları matematik öğretmenini çoğunlukla kadın, güler yüzlü, ayakta ders anlatan ve yazı tahtasına dört işlem ifadelerini yazan çizimlerle yansıtmışlardır. Ayrıca öğretmenlerin ders anlatımı esnasında elinde kitap, kalem ya da materyal tutan, elindeki kalem ya da çubukla yazı tahtasını gösteren, yazı tahtasının önünde ya da yanında durduğunu gösteren çizimlere yer verildiği gözlenmiştir. Matematik öğretmeninin yaptığ1 eğitimsel etkinliklerin ders anlatmak, derse giriş/çıkış yapmak, derse katılımı sağlamak, öğrencilerin matematik dersine yönelik olumlu duyguya sahip olmalarını sağlamak, öğrencileriyle iletişim kurmak ve sınav yapmak olarak ifade etmişlerdir. Literatür incelendiğinde öğretmenlerin matematiğe olumlu tutum geliştirmeyi sağlaması, yüksek motivasyona sahip olması, uygun öğretim yöntem ve tekniklerini kullanması, değerlendirme yapması, empati yapması, iyi öğretimi örnek alarak etkin olması gerektiği 
ifade edilmektedir (Doğan, 2000; Erickson, 1993; NCTM, 2000). Öğretmen adaylarının özellikle uygun öğretim yöntem ve tekniklerini kullanmaya değinmedikleri söylenebilir. Bunun nedeni öğretmenin sadece ders anlatmasına yönelmeleri olabilir.

Hem alanlar hem de sınıf düzeyleri dikkate alındığında; ders anlatmanın birinci etkinlik olarak belirtildiği, en az yer verilen etkinliğin ise sınav yapmak ya da olumsuz duyguya sahip olmak olduğu tespit edilmiştir. Yine hem alanlar hem de sınıf düzeyleri dikkate alındığında, birden fazla görüş bildiren öğretmen adaylarının ise matematik öğretmenini; en çok, ders anlatmasının yanı sıra derse katılımı sağlaması ya da öğrencileriyle iletişim kurması yönüyle tasvir ettikleri gözlenmektedir. Bu koşullarda en az değindikleri ya da hiç değinmedikleri ifadelerse çeşitlilik göstermektedir.

Öğretmen adaylarının çoğunlukla öğretmenlerin ders anlattıklarını ifade etmeleri Güven ve Karataş'ın (2004) araştırması ile de benzerlik göstermektedir. Baştürk'ün çalışmasında da (2011) bazı öğretmen adayları öğretim elemanlarının yapılandırmacılık yaklaşımına örnek olamadığını ifade etmiş̧ir. Diğer taraftan Baki ve Gökçek (2007) ise çalışmalarında yapılandırmacı yaklaşımın yanısıra geleneksel yaklaşıma yönelen öğretmen adaylarının da var olduğunu belirtmişlerdir. Öğrencilerle yapılan bir araştırmada da öğrencilerin öğrenci merkezli öğretimi tercih ettiklerine (Gökçek ve Güneş, 2011) değinilmiştir. Toluk-Uçar, Pişkin, Akkaş ve Taşçı (2010) da öğrencilerin, öğretmenlerini olumsuz nitelendirmelerle betimlerken, sahip olmak istedikleri öğretmenler için olumlu nitelendirmeler kullandıklarını belirtmiştir. Derse yönelik olumlu duyguya sahip olunmasını sağlama matematik öğretmenlerinin yaptıkları etkinliklerden biri olup Gökçek ve Baran Kaya (2017) da yaptıkları çalışmada öğretmen adaylarının eğlenceli öğrenme ortamlarını önemsediklerini belirtmiştir. Telli, Brok ve Çakıroğlu (2008) ise öğretmen ve öğrencilerce öğrencilerini motive etmenin önemine değinildiğini belirtmişlerdir. Olumlu duyguya sahip olan öğretmen için ise benzer şekilde Baki (2013) çalışmasında öğretmen adaylarının matematik öğretmenini sevecen gördüklerini ifade etmiştir. Gökçek ve Güneş (2011) ile Özyıldırım-Gümüş, Acar ve Yetkin-Özdemir (2015) de öğrencilerin, öğretmenlerini eğlenceli ders anlatırken görmek istediklerini belirtmiştir. Bu bağlamda öğrencilerin öğrenci merkezli öğretim istemelerine karşın, öğretmen adaylarının geleneksel öğretime yöneldikleri söylenebilir. Bunun nedeni, öğretmen adaylarının da geleneksel öğretimle yetişmelerinden ya da lisans programlarında öğrenciyi etkin kılan, merkeze alan öğretim yöntem ve tekniklerine yeterince yer verilmemesinden kaynaklanıyor olabilir.

Hizmet öncesi öğretmen adaylarının matematik öğrenen öğrenciye yönelik imajlarının nasıl olduğunu ortaya koymak üzere analiz edilen çizimlerinden ve açık uçlu soruların cevaplarından ortaya çıkan sonuçlar şöyledir; öğrenciler çoğunlukla sıralarında ders dinlerken ellerinde nesnelerle, parmak kaldırırken dersle ilgilenmezken ya da yazı tahtasına yazı yazarken resmedilmiştir. Öğretmen adayları öğrencilerin ders esnasında yaptıkları etkinliklere ilişkin açık uçlu soruya verdikleri cevaplarda ders 
dinlemek, derse giriş/çıkış yapmak, dersle ilgilenmemek, derse katılmak derse yönelik olumlu duyguya sahip olmak, öğretmenleriyle iletişim kurmak ve sınav olmak gibi ifadelere yer vermişlerdir. Literatür incelendiğinde öğrencilerin matematiği günlük hayatlarının parçası yapabilmesi, problem çözebilmesi, kendilerine güvenebilmesi, kendilerini geliştirebilmesi, olumlu tutum geliştirebilmesi (Anderson, 2007; MEB, 2017; NCTM, 1989, akt. Ersoy, 1997) için tek cevaplı sorulara değil anlamlandırıp çözmeleri gereken problemlere yönelmeleri, matematiği günlük hayatta kullanabilmeleri, kendilerini ifade edebilmeleri, sorgulayıp keşfedebilmeleri ve olumlu tutum sergileyebilmeleri gerekmektedir (Anderson, 2007; Doğan, 2000; NCTM, 2000). Bu bağlamda öğretmen adaylarının geleneksel yaklaşıma yöneldikleri için, matematiği günlük hayatla ilişkilendirmeye, sorgulamaya, keşfetmeye ve problem çözmeye değinmedikleri söylenebilir.

Hem alanlar hem de sınıf düzeyleri dikkate alındığında dördüncü sınıf düzeyindekiler hariç ders dinlemenin birinci etkinlik olarak belirtildiği gözlenmiştir. Dördüncü sınıf düzeyindeki öğretmen adayları ise derse yönelik olumlu duyguya sahip olmayı öncelikli olarak belirtmişlerdir. Hem alanlar hem de sınıf düzeyleri dikkate alındığında en az yer verilen etkinliklerin ise sınav olmak, derse ilgisiz kalmak ya da derse giriş/çıkış yapmak olduğu tespit edilmiştir. Yine hem alanlar hem de sınıf düzeyleri dikkate alındığında, birden fazla görüş bildiren öğretmen adayları ise sıklıkla matematiği öğrenen öğrencilerin ders dinlemenin yanı sıra derse yönelik olumlu duyguya sahip olduklarını belirtmişlerdir. Aynı koşullarda en az değindikleri ya da hiç değinmedikleri ifadelerse matematik öğretmeni sonuçlarına benzer şekilde çeşitlilik göstermektedir. Öğretmen adaylarının çoğunlukla öğrencilerin ders dinlediklerini ifade etmeleri Güven ve Karataş'ın (2004) araştırması ile de benzerlik göstermektedir. Güven ve Karataş'ın (2004) araştırmasında da geleneksel, öğretmen merkezli sınıf ortamlarının yansıtıldığı belirtilmektedir. Bu bağlamda öğretmen adaylarının geleneksel yaklaşıma yöneldikleri söylenebilir. Bu durum, öğretmen adaylarının da geleneksel yaklaşımla yetişmelerinden ya da lisans programlarında öğrenciyi merkeze alan öğretim yöntem ve tekniklerine yeterince yer verilmemesinden kaynaklanıyor olabilir.

Hizmet öncesi öğretmen adaylarının matematik öğretmenine ve matematiği öğrenen öğrenciye yönelik imajlarının nasıl olduğunu ortaya koymak üzere yapılan çalışmada elde edilen sonuçlar doğrultusunda araştırmaya dönük öneriler ise öğretmen eğitimine ve gelecekte yapılacak araştırmalara yönelik olarak açıklanmaktadır. Bu çalışmada sadece öğretmen imajlarını yansıtan çizimler değil onların çizimlerine temel oluşturulan bilişsel ve duyuşsal özellikler de anlaşılmaya çalışılmıştır. Çizimler bu özelliklerin ve deneyimlerin bir yansıması olarak kabul edilebilir. Öğretmenlerin matematiğin doğası ve rolü, matematiği öğrenen öğrenciler ve matematik öğretiminden sorumlu bir öğretmen olarak kendilerine yönelik sahip oldukları imajlar öğretim davranışlarını, öğretimi planlamalarını, okullarda matematik programının uygulanmasını ve gelişimini, ayrıca sınıf yönetimini ve iletişimini etkiler. $\mathrm{Bu}$ 
bağlamda öğretmen eğitiminde araştırma bulguları öğretmen eğitimi programlarının yapılandırılmasında ve öğretmen eğitimcilerinin eğitim durumlarının düzenlemesindeki önceliklerinin belirlenmesinde katkı sağlayabilir. Farklı öğretmen eğitimi programlarının bir çıktısı olarak imajlar analiz edilebilir.

Öğretmen adayları çizimlerinde kendilerini ders anlatırken, öğrencilerini de ders dinlerken resmetmişlerdir. Açık uçlu sorulara verdikleri cevaplar ve çizimlerinde yansıttıkları görseller incelendiğinde öğretmen merkezli bir yaklaşıma yöneldikleri gözlenmiştir. Bu durum, öğretmen yetiştirme programlarının yeniden gözden geçirilmesini gerektirebilir. Çünkü son yıllarda eğitimdeki yeni kavram ve yaklaşımların öğretmen imajlarına yansımadığı, çizimlerde bu yaklaşımların yansıtılmadığı gözlenmektedir. Bunun nedenleri araştırılabilir.

Ayrıca öğretmen ve öğrenci imajlarının karşılaştırılmasına yönelik korelasyonel ya da deneysel araştırma desenleri kullanılarak çalışmalar yürütülebilir. Bu çalışmada veri üçgenlemesi yapmak için çizim testleri açlk uçlu sorularla desteklenmiştir. Yürütülecek yeni çalışmalarda veri toplama yöntemi olarak görüşme ya da gözlemler yapılabilir. Öğretmenlik uygulamaları gözlenerek imaj testlerinde tespit edilen hususlar kontrol edilebilir ve bu amaçla yeni çalışma desenleri ve içerikleri tasarlanabilir. Öğretmenlik meslek bilgisi ders programları incelenerek, derslerde gözlemler yapılabilir. Bu derslerin işlenişi esnasında edinilen kazanımların öğretmen adaylarının imajlarını etkileyebileceği düşünülebilir. Bu bağlamda öğretmen adaylarının bu derslerin işlenişi ve bu derslerdeki kazanımlarının imajlarını nasıl etkilediğine yönelik görüşleri alınabilir. Ayrıca, öğretmen adaylarının imajlarında program ve sınıf düzeyine göre anlamlı bir farklılaşmanın olup olmadığını ortaya koymak üzere, benzer bir çalışma tüm sınıf düzeylerinde ve daha fazla alan öğretmenliği programına devam eden katılımcı sayısı arttırılarak tekrarlanabilir.

Bu çalışmada beklenen değeri 5'ten küçük gözenek sayısı \%20'yi aştığı için kay-kare analizi yapılamamış ve program türü ile sınıf düzeyine göre farklılaşma olup olmadığı belirlenememiştir. Başka bir veri setiyle farklı istatistiksel analizler kullanılarak bu çalışma yinelenebilir.

\section{Kaynaklar}

Anderson, R. (2007). Being a mathematics learner: four faces of identify. The Mathematics Educator, 17(1), 7-14.

Baki, Ş. (2013). Öğretmen adaylarının "matematik öğretmeni", "matematik" ve "matematik dersi" metaforik algıları. Mersin Üniversitesi Ĕ̆itim Fakültesi Dergisi, 9(1), 313-321.

Baki, A. ve Gökçek, T. (2007). Matematik öğretmeni adaylarının benimsedikleri öğretmen modeline ilişkin bazı ipuçları. Hacettepe Üniversitesi Ĕ̆itim Fakültesi Dergisi, 32, 22-31. 
Baştürk, S. (2011). Matematik öğretmen adaylarının eğitim fakültesindeki eğitim-öğretim sürecini değerlendirmeleri. Uluslararası İnsan Bilimleri Dergisi, 8(1).

Baydar, S.C. ve Bulut, S. (2002). Öğretmenlerin matematiğin doğası ve öğretimi ile ilgili inançlarının matematik eğitimindeki önemi. Hacettepe Üniversitesi Ĕ̆itim Fakültesi Dergisi, 23, 62-66.

Bozdoğan, Z. (2004). Etkili öğretmenlik eğitimi. Ankara: Nobel.

Doğan, M. (2000). Eğitim fakültelerinde okuyan aday öğretmenlerin matematiğg karşı tutumları. IV. Fen Bilimleri Eğitim Kongresi, Hacettepe Üniversitesi, Ankara, 6-8 Eylül.

Erickson, D. K. (1993). Middle school mathematics teachers' views of mathematics and mathematics education, their planning and classroom instruction, and student beliefs and achievement. Annual Meeting of the American Educational Research Association, Atlanta.

Ersoy, Y. (1997). Okullarda matematik eğitimi: Matematikte okur-yazarlık. Hacettepe Üniversitesi Eğitim Fakültesi Dergisi, 13, 115-120.

Gökçek, T. ve Baran Kaya, T. (2017). Ortaokul matematik öğretmeni adaylarının bakış açısıyla öğretmenlik mesleği ve lisans eğitiminin niteliği. Ahi Evran Üniversitesi Kırşehir Eğitim Fakültesi Dergisi, 18(1), 131-153.

Gökçek, T. ve Güneş, G. (2011). Öğrenciler matematik öğretmenini nasıl algılıyor? Mehmet Akif Ersoy Üniversitesi Sosyal Bilimler Enstitüsü Dergisi, 3(4), 1-9.

Guillaume, A. M., \& Kirtman, L. (2010). Mathematics stories: Preservice teachers' images and experiences as learners of mathematics. Issues in Teacher education, 19(1), 121-143.

Güven, B. ve Karataş, İ. (2004). İlköğretim matematik öğretmen adaylarının sınıf ortamı tasarımları. İlköğretim-Online, 3(1), 25-34.

Karasar, N. (2012). Bilimsel araştırma yöntemi. Ankara: Nobel.

Korkmaz, H. (2004). Fen öğretiminde alternatif değerlendirme yaklaşımları. Yeryüzü Yayıncılık, ISBN: 9756386-87-8.

Miles, M.B., \& Huberman, A.M. (1994). Qualitative data analysis: an expanded sourcebook. (2. bask1). California: SAGE .

MEB (Millî Eğitim Bakanlığı) (2017). PISA 2009 ulusal ön raporu. [Çevrim-içi: http://pisa.meb.gov.tr/wpcontent/uploads/2013/07/PISA-2009-Ulusal-On-Rapor.pdf, Erişim tarihi: Şubat 2020]

NCTM (National Council of Teachers of Mathematics) (2000). Principles and standards for school mathematics. Reston, VA. 
OECD (The Organisation for Economic Co-operation and Development) (2013). Education at a Glance 2013. [Çevrim-içi: http://www.oecd.org/education/eag2013\%20(eng)-FINAL\%2020\%20June\%202013.pdf, Erişim tarihi: Nisan 2020.]

Özyıldırım-Gümüş, F., Acar, T. ve Yetkin-Özdemir E. (2015). Ortaokul öğrencilerinin gözünden matematik öğretmenleri. Mehmet Akif Ersoy Üniversitesi Ĕ̆itim Fakültesi Dergisi, 34, 23-51.

Umay, A. (1996). Matematik eğitimi ve ölçülmesi. Hacettepe Üniversitesi Ĕ̆itim Fakültesi Dergisi, 12, 145149.

Sam, L. C. (1999). Public images of mathematics. Doctoral Dissertation. University of Exeter.

Sam, L. C., \& Ernest, P. (2008). A survey of public images of mathematics. Research in Mathematics Education, 2, 193-206.

Telli, S., Brok, P., \& Çakıroğlu, J. (2008). Teachers' and students' perceptions of the ideal teacher. Education and Science, 33(149), 118-128.

Thomas, J.A., Pedersen, J.E., \& Finson, K. (2001). Validaitng the draw-a-science-teacher-test checlist (DASTT-C): Exploring mental models and teacher beliefs. Journal of Csience Teacher Education, 12(3), 295-310.

Thompson, P.W. (1996). Imagery and the development of mathematical reasoning. L. P. Steffe, B. Greer, P. Nesher, P. Cobb \& G. Goldin (Eds.). Theories of learning mathematics. 267-283, Hillsdale: Erlbaum.

Toluk-Uçar, Z., Pişkin, M., Akkaş, E.N. ve Taşçı, D. (2010). Elementary students' beliefs about mathematics, mathematics' teachers and mathematicians. Ĕğitim ve Bilim, 35(155), 131-144.

Yalaz Atay, D. (2003). Öğretmen eğitiminin değişen yüzü. İstanbul: Nobel.

YÖK (Yükseköğretim Kurulu) (2007). Öğretmen yetiştirme ve eğitim fakülteleri. [Çevrim-içi: https://www.yok.gov.tr/Documents/Yayinlar/Yayinlarimiz/ogretmen-yetistirme-ve-egitimfakulteleri.pdf, Erişim tarihi: Şubat 2020.]

\section{ORCID}

Funda Uysal iD https://orcid.org/0000-0001-9929-9812

Hünkâr Korkmaz iD https://orcid.org/0000-0002-5289-1111

\section{Extended Summary}

Images of Teacher Candidates as a Mathematics Teacher on Themselves and Students Learning Mathematics

In higher education institutions that train prospective teachers, it is necessary to ensure that prospective teachers get to know their profession and to improve their perspectives on students. On the other hand, McDiarmid (1990) emphasizes the importance of knowing the cognitive and affective 
knowledge of prospective teachers (Baydar and Bulut, 2002). These experiences emphasize the image concept. Picture; it has a cognitive and emotional component that includes mental representation and attitude, emotions, anxiety, pleasure and fear. The image can be explained both by drawing and sentences (Sam, 1999). The aim of the present study is to determine the attitudes of the prospective teachers who are studying in the departments of elementary mathematics education, science education, and primary school education towards the mathematics teacher and the student who learns the mathematics when they start and complete the teacher training programs. In this context, an in-depth understanding was tried to be revealed for the cognitive and affective acquisitions of prospective teachers for mathematics teachers and students learning mathematics. The determination of the prospective teachers' images towards the mathematics teacher and the student learning mathematics is important in terms of demonstrating the points that teacher education should focus on and developing the teacher training program because while developing the program, dealing with the needs of teacher candidates in the context of determining the needs of individuals; it ensures that pre-service teachers participate effectively in the process by determining the target location and planning activities. This study will contribute to the field on account of the fact that it determines the cognitive and affective knowledge of the prospective teachers about the mathematics teacher and the student who learns the mathematics, gives an idea about what the prospective teachers will do when they become in-service teachers, shows the field knowledge that the prospective teachers have on the mathematics which will be taught at the beginning and at the end of the program, evaluates the attitudes of the prospective teachers towards the students who learn the mathematics, and identifies how well the prospective teachers know their profession. This study aims to investigate the images of first- and fourth-year elementary mathematics, science and elementary education teacher candidates about mathematics teachers and students.

In the survey research, it was tried to describe the perceptions of teacher candidates about mathematics teachers and students. 424 teacher candidates participated in the study. Data were collected by using a drawing form for teacher candidates. For the analyses of data, themes and codes were identified, and percentages were reported for the statements "often, rarely and never". In their drawings where they imagined themselves as mathematics teachers, they most commonly represented the mathematics teacher as lecturing. At least, they stated that the mathematics teacher has a negative feeling and makes the exam. They made drawings that showed that the mathematics teacher was mostly smiling, standing and writing four operations on the whiteboards. The fact that pre-service teachers express that the teachers teach lessons is similar to Güven and Karataş's (2004) research. In a study with students, it was mentioned that students prefer student-centered teaching (Gökçek \& Güneş, 2011). Toluk-Uçar, Pişkin, Akkaş and Taşçı (2010) also stated that students use positive qualifications for the 
teachers they want to have while describing their teachers with negative qualifications. Gökçek and Güneş (2011) and Özyıldırım-Gümüş, Acar and Yetkin-Özdemir (2015) also stated that students want to see their teachers while teaching enjoyable lessons. In this context, it can be said that pre-service teachers prefer traditional education, although students want student-centered education. The reason for this may be due to the fact that pre-service teachers are trained with traditional education or the teaching methods and techniques that make the student effective in the undergraduate programs are not included in the center. In their drawings where they imagined themselves as mathematics teachers, they most commonly represented the students as listening to the lecture. At least, they stated that the students learning mathematics were indifferent to the lesson or had an exam. They showed that students learning mathematics were mostly on their desks. The fact that pre-service teachers express that the students listen to lessons is similar to Güven and Karataş's (2004) research. In the research of Güven and Karataş (2004), it is stated that traditional, teacher-centered classroom environments are reflected. In this context, it can be said that teacher candidates tend to traditional approach. This may be due to the fact that teacher candidates are trained with a traditional approach or the teaching methods and techniques that place the student in the undergraduate programs are not sufficiently included.

In line with the results obtained in the study conducted to reveal how the pre-service teachers' images towards the mathematics teacher and the student learning the mathematics, the suggestions for the research are as follows; The reasons why they dream of their students while listening to the lesson can be explored as the teachers of the future. For this, interviews or observations can be made. Teaching practices can be observed. Observations can be made in the lessons by examining the teaching profession curriculum. Since this may be due to the lessons being taught in teacher training programs, opinions can be obtained from prospective teachers. In addition, because the mathematics teacher and the students do in the drawings of prospective teachers; a similar study can be repeated by increasing the number of participants in order to reveal whether there is a significant difference according to the program and grade level they are studying. Since the number of pores less than five in the expected value exceeds $20 \%$ in this study, it was not possible to make a chi-square and it was not possible to determine whether there was any difference according to the program type and the grade level. Practical suggestions that can be expressed in line with the results of the research are as follows; While teaching themselves as the teachers of the future, they saw their students while listening to the lessons and turned towards a teacher-centered approach. This may require a revision of teacher training programs. To this end, they can be encouraged to do their teaching practices in order to create a learning environment that their students will discover and learn under their guidance in the future. In teaching profession lessons, it can be emphasized what such an approach may result. Teacher trainers can also be models in field education, teaching professional knowledge and general culture courses. 